\title{
Limits to Globalisation and the Loss of Faith
}

\author{
Philip Goodchild
}

The contemporary rise of populism may be explained as a product of the process of globalisation against which it reacts. For globalisation rests upon a faith in the future, and limits to globalisation necessitate a change in faith. It is proposed that the nature of this faith in the future can be illuminated by the dynamics of a credit crisis, such as the Great Financial Crisis of 2007-8. According to new economic theory, economic growth is driven by the rate of credit creation, and economic downturns result from a failure in mutual confidence. There are both mathematical and external limits to economic growth. The first result of approaching such limits is an attempt to retain one's share of resources with the rise of populism. A subsequent result may well be a return to religion in currently secular countries.

Faith; Globalisation; Credit; Finance; Crisis of Representation; Sacrifice

Philip Goodchild is Professor of Religion and Philosophy at the University of Nottingham, UK. His main books include: Deleuze and Guattari: An Introduction to the Politics of Desire (1996), Capitalism and Religion: The Price of Piety (2002), Theology of Money (2007), (edited) Philosophy as a Spiritual Exercise: A Symposium (2013). He is currently completing a book Credit and Faith: A Philosophy of Theological Economics.

\section{Introduction}

The rise of populist, authoritarian, nationalist and protectionist rulers in developing and advanced economies alike is often understood as a crisis of democratic representation: populist majorities strengthen their advantages over migrants and minorities. This conflict may be mapped against at least three axes. On one axis, there is political conflict between those who promote national, ethnic and religious identities over against those who are identified as 'other' in respect of origin, ethnicity, or religious or sexual identity. On another axis, there is political conflict between those for whom globalisation has enhanced prosperity and opportunity and those who fear that others are prospering at their expense. On a third axis, there is political conflict between those who seek to ground public discourse in evidence, working within political and economic constraints, and those whose public discourse is either calculated to produce particular effects or else simply expresses wishful thinking and resentment. Cosmopolitan, global, and rational 
citizens may perceive a crisis of democratic representation when the interests of diverse peoples, prosperous trade, and truth are set aside. ${ }^{1}$

It is therefore counterintuitive to propose that a root cause of this contemporary crisis lies in the progress of globalisation itself. There is a crisis of democratic representation when people sense that the decisions, forces and necessities that shape their lives derive from elsewhere. For governments are constrained not only by the wishes of their populace but also by the demands of economic and physical security. This constraint is a natural outcome of a far more interconnected world which has brought with it not only increased opportunities but also threats such as international terrorism, climate change, financial crises, and mass migration. Furthermore, lasting constraints are imposed by democratic representatives: trade agreements, which are complex contracts, involve promises which govern one's own nation's conduct, and, in the most complex cases, develop institutions external to the ongoing democratic process to regulate what has already been agreed. In other words, there is a tension between an ideal of democratic autonomy, where liberty consists in the ability to engage in free market exchange, and the reality of democratic representation, where trade involves contract and external constraint. Finally, since people have little understanding of the consequences which might emerge from agreements in a complex world of capitalist creative destruction and ecological interdependence, there remains some distance between the rational foresight which grounds political choices and ultimate outcomes. In other words, globalisation, understood as the advance of free market exchange and democratic institutions, exposes itself to mobile forces, constraints, and disconnections with external reality which undermine its own progress.

In this respect, globalisation, like the populism which contests it, rests upon a faith. The purpose of this article is to shed some light on the nature of this faith in order to explain the political transformations of our time. The aim is to lay out a framework for understanding religious and secular faith alike. For the roles of credit and faith in driving economic life may also hold significance for future transformations of religion. Indeed, if the social function of religion as a basis for underwriting trust has been eclipsed by faith in the future, then a loss of that faith may lead to a return of religion. More specifically, the argument proposed here is that the dynamics of a credit crisis, such as the Great Financial Crisis of 2007-8, may also shed some light on the dynamics of the political crisis of representation.

Any investment, whether financial, political or religious, involves an assessment of both the value that is on offer and the degree of security afforded. Many previous societies have found that value and security in their own past - in the establishment of custom and tradition, in the great achievements of the nation, or in the revelations or ideas of founding fathers, whether Confucius, Manu, St Paul,

1 For recent commentary on such political changes, see Heinrich Geiselberger (ed.), The Great Regression (Cambridge: Polity, 2017). 
Mohammed, Jean-Jacques Rousseau, Thomas Jefferson, or Karl Marx. What is distinctive about the age of globalisation is cooperation beyond the boundaries of nation, creed, ethnicity, linguistic group, or political ideology, expressed in the form of the free movement of people, goods, services and capital. Far from appealing to a common heritage, the common good of globalisation is future prosperity. Global cooperation is based on promises, and promises offer a value and security that is to be found in the future. Just as each person who takes on a debt, whether for investment or consumption, expects to pay out of the resources provided by a wealthier future, so also each person who makes a political commitment to increasing openness and engagement expects to receive greater value and security. This wealthier future is itself provided by globalisation, the increase in exchange that generates wealth. In distinction from previous societies, our relations to each other in an age of globalisation are founded no longer on our relation to a common past, that which we are given, but on our relation to a common future, that which we can make. Traditional religions have been displaced by projection.

Now, any relation to the future is a matter of faith. Faith in a prosperous future makes cooperation possible; cooperation makes prosperity possible; and hope for future prosperity is a ground for faith. This has functioned as a benign circle. Yet any future threat will prove destructive if it undermines confidence. There are perhaps three kinds of response that aim to maintain confidence in the face of future threats: a first is the technocratic paradigm which hopes that a solution to the problem can be found through ingenuity, investment and commitment. A second response is denial: refusing to face up to the significance of future threats so as to continue as before. A third response is to advocate a return to an image of cooperation founded on the past. These three responses, in various mixtures, determine the main political options of our time.

The age of globalisation is also, in certain respects, an age of secularisation: a common religion is not necessary for mutual trust and cooperation. Religious faith may be acceptable as a personal option, but economic relations with others have to be regulated in practice by the worldly realities of states and markets. When economic globalisation offers an immanent frame for extending trust and cooperation, religious imperatives, based on obligation, become less significant. Nevertheless, there is a sense in which faith, which was formerly directed first of all towards God, is now directed towards each other through the mediation of states and markets. Prosperity is no longer regarded as a gift of God, but is the natural outcome of ingenuity, discipline and cooperation. This immanent frame consists in confidence in the faithfulness of others. The ground that supports such mutual trust is the value and security afforded in the future by cooperation itself. In this respect, investing in globalisation bears some resemblance to a speculative bubble: when others are investing, the price continues to rise, and investment seems attractive, but the moment there is hesitation, the price can start to fall, and the disinvestment is sudden and catastrophic. It is possible that globalisation is 
being kept afloat by our technocrats, by our reality deniers, and by our nationalists. It is also possible that it might experience a sudden, catastrophic collapse.

\section{The Emptiness of the Future}

One day global market capitalism will come to an end. Whether destroyed by an external shock, such as a nuclear winter, or undermined by its own economic dynamics, such as a spiral of hyper-inflation or debt deflation, or overturned from within, by a religious revolution or by runaway artificial intelligence, or displaced by another socio-economic system as yet barely imaginable, capitalism will have its last day. Now, any foresight into such an end leads to a problem of backwards induction. ${ }^{2}$ For on the last day, investments may no longer yield a profit, debts may no longer be repaid, work may no longer yield wages, and money may no longer store value. On the penultimate day, then, why should anyone with foresight make investments, offer loans, or turn up for work? In other words, if the end is recognised, capitalism will destroy itself on the penultimate day - the end will come before it has arrived. Having recognised this, then one should also recognise it the day before the penultimate day, and so bring the end a day nearer, and again and again until we reach our present day. One day global market capitalism will come to an end. Should foresight into the end of capitalism be sufficient to destroy it here and now? Has capitalism already become bankrupt, and do people live in denial of the fundamental emptiness of all investment, all debt, and all money? For if our debts, at any moment, should prove unpayable, why attribute them such significance here and now? Of course, any insight into the empty foundations of financial value cuts both ways: if it is advantageous in the short-term to undertake unpayable debts and to invest in the debts of others, why not continue to do so until the date of the end of capitalism is clear?

The point of this thought experiment is to disclose that an essential economic resource, enabling investment, borrowing and even modern money itself, is faith in future prosperity achieved through economic cooperation. Cooperation is founded upon faith in a future, yet this future is to be achieved through cooperation itself. Capitalism must collapse without such confidence. In this respect, global market capitalism as a whole bears some structural resemblance to an investment bubble: it feeds its own growth through expectation. It does not matter whether the asset is in reality over-valued, for so long as others are investing in expectation that the price will rise, then, in the short-term, the price will rise and profits can be made. The prosperous future arrives to the extent that we believe in it and cooperate to achieve it. Now the condition for the emergence of an investment bubble is the use of leverage or trading on margin so that an investor

2 Jean-Pierre Dupuy, Economy and the Future: A Crisis of Faith, trans. M.D. DeBevoise (East Lansing, MI: Michigan State University Press, 2014), 65. 
provides only a proportion of the nominal asset price. The simplest form of credit is deferral of payment - for example, in the tulip mania of Amsterdam in the 1630s or the South Sea Bubble of London in 1720, assets changed hands in exchange for deposits of $10 \%$ of their nominal value. ${ }^{3}$ The balance was still owed, and speculators were debtors: people would pay later, or rather, not at all, for if the asset rose just another $10 \%$ in value, one could sell it on and double one's original investment. In those instances, while fortunes were made and lost, the investment bubbles collapsed. Yet the form of capitalism that emerged from that era, initially relying for value on the debts undertaken by the Bank of Amsterdam or the Bank of England, ${ }^{4}$ has survived. It is based on promises to pay in the future, whether those promises are banknotes, financial derivatives, insurance contracts or employment contracts. Such debts have proven more secure when founded on the mutual exchange of debts between sovereign states, private investors, and the banking system. The Financial Revolution in England generated a long-term national debt, an active securities market and a widely circulating credit currency, enabling a global empire and the Industrial Revolution. ${ }^{5}$ The key economic agents are all dependent on each other paying their debts, and, as such, their behaviour becomes more disciplined and predictable. This exchange of debts expresses a faith in economic cooperation and ongoing prosperity. Of course, past performance, even over the course of three centuries, is not a reliable guide to future profits. If the conditions under which capitalism has thrived were to cease then this would send a shock wave in advance through its effect on expectations.

It may be that reaching the limits of globalisation and economic growth, with a consequent loss of faith in a prosperous future, may offer some explanation for the political transformations of our time. When there is less promise of a future to be obtained through cooperation it may seem more urgent to defend what one has: it is a matter of circling the wagons to keep out outsiders, or staking a claim to the property one enjoys. I wish to point out three salient aspects of a faith grounded in future prosperity. Firstly, faith in the future is founded upon a faith in faith, a confidence that others will keep faith. Of course, people try to support such faith with rationalisations based on past trends towards growth and current technological progress. But there are no future facts; our grounds for faith in the future rest upon confidence alone. Secondly, in order to maintain continuing confidence, people must avert their gaze from future dangers. Few people are interested in understanding how the world truly is; instead, they focus upon how they wish it to

3 James Buchan, Frozen Desire: An Inquiry into the Meaning of Money (London: Picador, 1998), 107-12; Andreas Andréadès, History of the Bank of England 1640-1903 (London: Frank Cass, 1966), 135.

4 John K. Galbraith, Money: Whence it came, where it went (London: André Deutsch, 1975), 18-44.

5 Carl Wennerlind, Casualties of Credit: The English Financial Revolution 1620-1720 (Cambridge, MA: Harvard University Press, 2015), 1. 
be. Thirdly, as a consequence of an unacknowledged anxiety, people keep a suspicious eye upon each other so that if dangers are realised they can react ahead of or with the crowd; one cannot afford to be the one left behind holding worthless assets and collateral. These structural features of the psychology of a speculator, inherent in capitalism since its inception in the early modern financial revolution, have only been amplified by the most recent financial revolution through which finance has come to predominate in the creation of asset values, and daily lives have become increasingly structured through debt. ${ }^{6}$

Classical conceptions of capitalism understand it in terms of saving, the accumulation of the means of production. ${ }^{7}$ Historically, this may be a misconception, for the first industrialists in England each mortgaged their land to fund their investments. ${ }^{8}$ Yet what is especially striking about the recent period of globalisation, since around 1980, is the extent to which personal, corporate, financial, and government debt has increased in most countries. Whether debt is used for investment, consumption, for balancing cashflow, or to pay essential bills, it involves a speculative wager on the future. For those who sit on the boards of secure and profitable companies, capitalism is simply a prudent way of freely handling property and agreement, and its excesses may be curbed by virtuous conduct. ${ }^{9}$ For those for whom economic opportunities are only available through debt, by contrast, conduct is determined in the last instance by debt obligations. Projection of the future, drawing on the psychology of a speculator, may be more pervasive than we might suppose: in addition to the growth in finance, speculation and debt which has accompanied the era of globalisation, projection is found in both faith in globalisation itself and in the monetary architecture which underpins capitalism.

\section{Limits to Globalisation}

There is some evidence to suggest that faith in a more prosperous future is declining. In 2013, a Pew Research Center survey asked people in developed countries whether they expected their children to enjoy a higher standard of living than themselves. A reassuringly positive answer was returned by just $33 \%$ in the

6 Andrew Ross, Creditocracy and the Case for Debt Refusal (New York: OR Books, 2013).

7 This view is shared by Karl Marx, with his appeal to primitive accumulation, and Max Weber, with his appeal to the Protestant ethic. Karl Marx, Capital: Volume 1 (Harmondsworth: Penguin, 1976); Max Weber, The Protestant Ethic and the Spirit of Capitalism, trans. Talcott Parsons (London: Allen and Unwin, 1965).

8 Andro Linklater, Owning the Earth: The Transforming History of Land Ownership (London: Bloomsbury, 2015), 181.

9 See Kenneth J. Barnes, Redeeming Capitalism (Grand Rapids, MI: Eerdmanns, 2018). 
US, $28 \%$ in Germany, $17 \%$ in Britain, $14 \%$ in Italy, and $9 \%$ in France. ${ }^{10}$ The experiences that motivate such pessimism might include stagnant wages, increasing levels of debt, unaffordable housing, insecure employment, the loss of a social safety net through austerity measures, observed declines in physical and mental health, warnings of inadequate pensions, and epidemics of social isolation. It is in such ways that people may experience at an individual level the lacklustre performance of national economies. The critical question is this: what happens to globalisation when people lose faith in a more prosperous future?

The question of whether economic growth undermines its own future prosperity through its own success, whether through pollution, depletion of resources, or an ageing population, ${ }^{11}$ may be less immediately relevant here than the internal dependence of the economy on credit. Globalisation is based on a faith in increasing exchange, including the mobility of goods, services, labour and capital, as the route toward prosperity for all. This faith in exchange is supported by three key elements: hope for future prosperity, based on evidence of increasing wealth; confidence in the stability of the global financial system, as the infrastructure mediating investment, borrowing and exchange; and effective wealth distribution, for exchange can only be trusted as a route to accumulation if there is a realistic chance of obtaining wealth. Any future limits to globalisation from each of these dimensions offers a present limit to faith in globalisation itself. If economic growth starts to falter then income and profits can only be drawn by some at the expense of others. Once the future no longer appears to be a reservoir of prosperity, a source of motivation for investing credit and a source of collateral for undertaking debt, then a far more defensive political dynamic will start to emerge.

One limit to globalisation is offered by increasing financial instability. Those who trade from their own resources can grow richer or poorer, but those institutions or people who are highly-leveraged, drawing on borrowed money, are exposed to risks. If global debt in the non-financial sector was around $269 \%$ of GDP in 2007, after a decade of austerity and deleveraging it reached $273 \%$ in $2016 .{ }^{12}$ Such levels of debt make the system unstable: while there is some insurance against defaulting debtors, once the rate of default crosses a critical threshold then it spreads through the wider economy by contagion, for those who depend upon the debt repayments of others may not be able to meet their own obligations in turn. There have been few regulatory changes affecting banking and

10 Cited in Satyajit Das, A Banquet of Consequences: Have We Consumed our Own Future? (London: Financial Times, 2016), 3.

11 These are other issues are surveyed in Satyajit Das' comprehensive survey, $A$ Banquet of Consequences.

12 See Bank for International Settlements, Statistical Bulletin, December 2017, 283. The average public (government) debt to GDP ratio of advanced economies rose by $30 \%$ of GDP in the decade following the financial crisis. See Bank for International Settlements, Statistical Bulletin, December 2017, 281. 
the trading of derivatives since 2007, and central bankers are largely agreed that future credit crises are inevitable. ${ }^{13}$ Even China, which sought to avoid the mistakes of the West with sovereign control over credit creation and expansionist fiscal policy, has gone from a total debt to GDP ratio of $150 \%$ in 2007 to $280 \%$. Financial collapse, the unravelling of chains of credit, causes liquidity problems in the real economy, bankruptcies, unemployment, lack of investment, and the threat of a debt-deflationary spiral. When the stability of the global financial system cannot be trusted, globalisation goes into reverse.

A further limit to globalisation is rising inequality. Once the world's eight richest individuals own as much wealth as the poorer half of the global population, then global inequality has reached an extreme. ${ }^{14}$ Two of the mechanisms that drive the growth in inequality may be revealed by looking specifically at where money comes from and to where it flows. Inequality is driven by a spiral of speculative borrowing to invest in real estate and financial assets: such borrowing leads to price rises and capital gains for the owners of assets, and these lead in turn to increased borrowing and investment in unproductive assets; in the meantime, real production is deprived of investment, and those without assets are increasingly priced out of a global speculative bubble. ${ }^{15}$ Inequality is also driven by the existence of large corporations, since the money used to pay to consume goods and services is extracted from local economies, and less of that money returns if the large corporations have few suppliers in those regions. ${ }^{16}$ With the prospects for gaining wealth through hard work and innovation receding, faith in a prosperous future for the majority is rapidly eroding. Each of these dynamics undermines faith in globalisation and exchange, and loss of faith sets real limits to globalisation.

\section{The Dynamics of Debt}

If these limits operate first at the level of faith and subsequently at the level of production, there are also limits operative at a purely economic level through the dynamics of debt. This phenomenon calls for a shift in understanding: it now seems that global market capitalism is driven by debt creation or deferral of payment. According to previous economic theory, debt has no aggregate effects on the economy as a whole, for by definition, for every debtor there must be an

13 Mervyn King, The End of Alchemy: Money, Banking and the Future of the Global Economy (London: Little, Brown, 2016), 335-7.

14 See Oxfam, An Economy for the 99 \% report January 2017.

15 Adair Turner, Between Debt and the Devil: Money, Credit and Fixing Global Finance (Princeton, NJ: Princeton University Press, 2016), ch. 4.

16 Richard Douthwaite, Short Circuit: strengthening local economies for security in an unstable world (Dublin: Lilliput Press, 1996). 
equivalent creditor. ${ }^{17}$ Whatever the debtor has borrowed to spend, the creditor is unable to use. The fundamental misconception here is to imagine that all economic transactions are exchanges, for some are mere promises. Debts and credits are created out of nothing when settlement is deferred. Such debts become valuable assets that can be transferred as a means of payment. Finance as a whole is irreducible to instantaneous market exchange because it consists entirely in the temporal reality of deferred payment. ${ }^{18}$ In this respect, one can distinguish separable yet interdependent dimensions of a market economy: while people engage in exchange transactions, such that one person's financial asset is always balanced by another's liability, banks also have another function: they settle debts with each other. Since such mutual debts between a few banking institutions cancel each other out, banks do not need to receive or borrow the vast majority of the money which they lend. ${ }^{19}$ As the Bank of England's paper, 'Money Creation in the Modern Economy', makes clear: 'Whenever a bank makes a loan, it simultaneously creates a matching deposit in the borrower's bank account, thereby creating new money. ${ }^{20}$ For when money is created by banks through issuing loans, the mutual credits and debts cancel each other out. It is quite straightforward to create mutual debts out of nothing. The borrower has the liability of owing the loan as well as the asset of the money to spend in their bank account. Since these are equal, and cancel each other out, it is as though the borrower is their own creditor. Likewise, the bank has the new asset of a loan that will be repaid, while having the liability of creating a deposit to be spent immediately. Since these are equal and cancel each other out, it is as though the bank is its own depositor. So banks do not need the money they lend in advance. As the nineteenth century Swedish economist Knut Wicksell made clear, the banks are able to do this because they settle debts with each other, and such debts cancel each other out through clearing transactions. ${ }^{21}$ This creation of credit adds to aggregate demand in an economy, eventually funding both consumption and purchases. Yet it arises from nothing, for in clearing transactions between banks they simply cancel out the mutual sums owing. In short, purchasing power or real, effective demand is created through an apparently mutually-cancelling creation of paired credits and debts.

This has enormous consequences as money creation becomes increasingly deregulated. In the case of the UK, household debt was stable around $15 \%$ in the

17 For example, Paul Krugman still holds this view, which fails to understand the nature of money creation. Steve Keen, Can We Avoid Another Financial Crisis? (Cambridge: Polity, 2017), 53.

18 Massimo Amato and Luca Fantacci, The End of Finance (Cambridge: Polity, 2012).

19 Ann Pettifor, The Production of Money (London: Verso, 2017).

20 Michael McLeay, Amar Radia and Ryland Thomas, "Money creation in the modern economy", in: Bank of England Quarterly Bulletin Q1 2014, 14-28.

21 Knut Wicksell, Interest and Prices, trans. R.F. Kahn (London: Macmillan, 1936), 68. 
1960s, but started to rise rapidly in the 1980s due to financial deregulation until it reached $95 \%$ of GDP in $2007 .^{22}$ This is newly created money, at a rate of about $1.5 \%$ of GDP per year. An increase of little more than $1.5 \%$ per year may sound small, but notice what is meant by these figures. Consider the money that is spent on a credit card in a shop: this is then used to pay wages, suppliers, and investors, who in turn will spend or invest the money, leading to a multitude of transactions each of which counts towards GDP, all making use of that same created money. If all that newly created money was re-spent 66 times in the course of one year, passing from one bank account to another, then it would be the basis for almost the whole of the GDP - of course, it can't be spent that often in reality, for there is also corporate and government borrowing to consider, as well as the excess borrowing from previous years that is still recirculating. An entire economy can live by borrowing alone, gaining access to goods and services for nothing more than promises or debts; others within the economy or beyond can provide the goods and services, treating the debts as money. This is an economy in radical disequilibrium, where investment bubbles and credit crises punctuate the underlying growth in debt.

There is also another dynamic to consider: debt may continue to grow whether an economy itself grows or shrinks. The mechanism works like this: when debt is issued against collateral, such as a mortgage based on the value of a house, then the quantity of debt is fixed, while the value of the asset will fluctuate with supply and demand. ${ }^{23}$ In a downturn, when asset prices fall because there is a rush to sell, debt remains fixed. Wealth decreases in a downturn, but debts do not; the level of debt remains stuck at its existing rate, while there is less collateral in the economy to support it. Likewise, when people deleverage and pay down their debts, they reduce the amount of money circulating in the economy. With less money around, demand goes down and businesses contract, leading to unemployment, less investment, and less income from which debts can be serviced. In Irving Fisher's description of a debt-deflationary spiral, the more debtors pay off, the more they owe. ${ }^{24}$ In other words, whether the economy grows or shrinks, the level of private debt relative to GDP stays ratcheted up.

These dynamics have been given a mathematical description by the Australian economist Steve Keen, who has shown that the aggregate demand that drives an economy is given by the sum of GDP plus the growth in credit. ${ }^{25}$ In other words, while a growing economy can drive itself, with money circulating faster and faster, an economy can also be driven by an increase in private debt, for this is new money creation that adds to demand even when this exceeds the rate of growth. Credit

22 Turner, Between Debt and the Devil, 22.

23 Philip Coggan, Paper Promises: Money, Debt and the New World Order (London: Allen Lane, 2011), 134-5.

24 Cited in Keen, Can We Avoid Another Financial Crisis, 115.

25 Keen, Can We Avoid Another Financial Crisis, 56. 
creation is the volatile factor here. If private debt is small relative to GDP, then changes in borrowing habits have less significance within a growing economy; yet once private debt is large relative to GDP, a change in borrowing can easily outweigh any previous GDP growth. Keen suggests that the key threshold is when private debt reaches about $150 \%$ of GDP. ${ }^{26}$ Beyond this threshold any economic downturn paralyses an economy such that debt repayment becomes impossible, and the demand for increasing credit falls away. If Japan reached this state of a 'zombie economy' in 1990, then in 2008 it was joined by Denmark, Ireland, the Netherlands, New Zealand, Portugal, Spain and the UK. ${ }^{27}$ While Ireland has succeeded in further expanding its growth in credit, current ratios of private debt to GDP suggest that it will be joined shortly in the next economic crisis by Australia, Belgium, Canada, China, Hong Kong, Korea, Norway and Sweden. ${ }^{28}$ The other advanced economies rely on exports to the highly-indebted economies. The drop in demand from their neighbours will present the kind of difficulties faced by China in 2008, threatening recession. China itself chose to follow the debtor countries by stimulating demand through internal credit creation; it has now joined the highly-indebted countries. National differences and choices aside, this mechanism of debt overwhelming productive growth operates in the global economy as a whole.

The underlying point is that global market capitalism is fuelled by debt, and there are internal, mathematical limits to debt-driven economic growth. These internal limits exist alongside any external or ecological limits. Once overall levels of debt rise, most funds are directed towards debt service, crowding out both consumption and investment. In a stagnant economy, profits can only be earned by the extraction of wealth from others. Such extraction is not new, but it had previously been disguised by the promise of inclusion in wealth creation through the globalisation of knowledge, skills, productive capacity, and governance. Once growth falters, one can only profit at another's expense. Moreover, the global middle classes had benefited substantially from such extraction of wealth, whether directly through cheap goods and services or indirectly through rising asset prices. The wealth of such middle classes is becoming the primary object of contemporary extraction through debt, for asset values are now much more significant than cheap labour in the extraction of wealth. Yet once there are limits to the economic creation of wealth, whether environmental or economic, then the technical knowledge that increases productive capacity will prove redundant. The clearer the evidence becomes for stagnating prosperity, financial instability, and rising inequality, then the less authority will be granted to an ideal of globalisation with its modern rationalised culture and its technocratic paradigms of reason. In short, we stand at the threshold of a crisis of faith. What will happen to global-

\footnotetext{
26 Keen, Can We Avoid Another Financial Crisis, 81.

27 Keen, Can We Avoid Another Financial Crisis, 87.

28 Keen, Can We Avoid Another Financial Crisis, 97.
} 
isation when there is no longer faith in rising prosperity, in financial stability, and in economic opportunity? The first indications are that people will endeavour to safeguard their share of a shrinking resource base.

\section{The Role of Religion}

Lastly, we may turn to consider the relevance of religion here. Human prosperity and well-being depend in large measure upon ongoing cooperation: mutual trust is the principal source of wealth. While trust in one's immediate neighbours is straightforward if it is deserved, trust in those whom one rarely meets, or in those whom one does not meet at all, is a far more momentous, yet rather more fragile, affair. In this respect, it may be helpful to understand the process of secularisation not as the end of religion but as the transference of faith from received revelation to willed projection. Where revelation sustains trust around the past, projection sustains trust in the future; where revelation appeals to a transcendent origin, projection appeals to an immanent construction; and where revelation offers a given content, projection is empty of content but for faith in faith itself. Form, the mode of organisation, displaces content. The twentieth-century has witnessed the extension of a cumulatively more momentous and yet fragile apparatus of trust: economic globalisation. Distant people may be trusted to the extent that they are incorporated into a framework for guiding conduct based on contract and exchange, monetary transactions, audited accounting, regulation and enforcement of trading standards, stable government, employment in corporations, and an infrastructure for transport and communication - all contributing towards the free movement of goods and services, workers, and capital investment. At the same time, such mobility also has the effect of uprooting people from previous frameworks of trust: when products, people and investment capital are scattered far from the living communities in which they first emerged, modernisation and rationalisation tend to replace the prior customs that gave identity and orientation to human conduct. Trust in living traditions is undermined, being replaced by trust in products, procedures, systems, governments and money.

This is immensely unsettling. It is therefore hardly surprising that the twentieth-century has also witnessed another momentous transformation of frameworks for trust throughout the majority world: the spread of world religions, or more specifically, Pentecostal Christianity, Roman Catholicism, indigenous Christianities, Sunni Islam, and neo-Hinduism, as well as more minor religious movements. ${ }^{29}$ Whatever processes of secularisation may have been operative in Europe, North America and Japan, the twentieth century has largely witnessed

29 Olivier Roy explains the contemporary spread of religion as a response to deculturation. See Olivier Roy, Holy Ignorance: When Religion and Culture Part Ways (Oxford: Oxford University Press, 2014). 
the triumph of religion - a cultural transformation which, emerging from much longer histories, may perhaps prove to be rather more stable and enduring than economic globalisation. Moreover, in situations where the very existence of trust and community has been under threat, whether as a result of war or as a byproduct of the disruptions wrought by economic globalisation, world religions have proved effective in re-establishing a basis for organised, meaningful conduct and mutual trust.

This suggests an unforeseen prospect: if faith in debt-driven capitalism collapses, along with the benefits of globalisation, peace and prosperity that it brings, there will be a change in where people place their faith. Initially, loss of faith may lead to the behaviour of a desperate debtor who endeavours to postpone future settlement as far as possible, funding debt with more debt. Attention is focused upon opportunities to make money in the here and now, while others come to be regarded primarily as competitors in a market that scarcely feeds us all. In short, debt-fuelled capitalism promotes the psychological dynamics of an investment bubble, involving practical denial of the future, inattention to reality, and a purely extrinsic relation to others. This is what Carl Wennerlind has called 'credit fetishism', to be contrasted with Marx' money fetishism: 'if money allows people to disregard the origins of value, credit on the other hand necessitates a careful construction of a social imaginary of the reality within which future values will be produced. Money frees people from thinking about the past conditions of production, while credit necessitates that future conditions are carefully considered and vividly imagined. ${ }^{30}$ This imagined future reality, since it is the key to wealth, may deliberately conceal real conditions. ${ }^{31}$

This credit fetishism is intensified for those from whom value is extracted, just as it is intensified for those who draw a profit. The problem, however, is compounded in this way: for those whose entire lives have been immersed in a culture of individualism, wish-fulfilment, and a focus on the images projected by others have few intellectual resources through which to open their eyes to the dynamic relations that constitute reality. Modern cultures are largely hollowed out by heteronomy and isolation in place of collective responsibility, by the pursuit of wishes in place of finding meaning in collective purpose, and by a focus on images and identities instead of causal and human relations. As such, they may lack the basic skills of intelligence, courtesy, self-criticism, and diplomacy necessary for any adaptive response to a changing reality. Despair takes the form of a nostalgia for a lost collective identity, infantile rage against the denial of wishes, and an obsession with the threats posed by images of others. These sentiments may then be manifest in political shifts towards regional secession, national autonomy,

30 Wennerlind, Casualties of Credit, 230.

31 Wennerlind develops this conception of credit fetishism in a discussion of the belief in the unlimited profitability of the South Seas slave trade in 1720, which overlooked the agency and mortality of the slaves themselves. 
control over borders and right-wing politicians. It is hardly likely that any of these gestures will offer a successful way of addressing the new economic reality.

Nevertheless, however much conflict is generated by the new politicians, the rise of this new politics is part of a global process. Just as the rise of new religious visibilities may be explained by the deculturing effects of globalisation, the rise of a new politics can be explained as a result of the transformations of faith. In other words, the reaction against globalisation is itself a global process, even if it accelerates the production of conflict and chaos. Under modern conditions of fragmentation, a route out of chaos has often been offered by religion, for religions offer a framework for self-discipline, mutual trust and cooperation. If the developed world loses faith in a cooperative and prosperous future, if the wealth of the many is extracted by the few, and if globalisation collapses into fragmentation and conflict, then we may well see a resurgence of religious commitment in currently secular countries. For where secularising globalisation offers people the opportunity to save themselves through their own efforts, world religions offer to save people from themselves. Where globalisation offered the salvation of future prosperity through the cooperation that overcomes individual differences, world religions may offer salvation from isolation and anarchy. Such religions may not often take a form of which modern, critical theologians could approve. They might found trust on a wilful denial of patent reality; they might deny ecological concerns and promote war. Yet they might also offer some defence against economic catastrophe and a universal loss of trust by offering a basis for human cooperation. For where economic globalisation is based on an exchange of mere promises, debts which are treated as collateral for other debts, religious life offers the substance of a life regulated by religious piety. Prior to the financial revolution this was the basis for economic life. ${ }^{32}$ Following the crisis of capitalism it may become so once again.

Such considerations leave one key question outstanding for the purposes of a critical understanding of religion. To what extent have traditional religions always functioned according to the emotional logic of an investment bubble $?^{33}$ Perhaps the issue turns on the leverage or downpayment involved. According to Paul's gospel, it is God who makes the initial downpayment of the Holy Spirit. ${ }^{34}$ If, by

32 Craig Muldrew, The Economy of Obligation: The Culture of Credit and Social Relations in Early Modern England (Basingstoke: Palgrave, 1998), 311; for the Islamic basis for economy, see David Graeber, Debt: The First 5000 Years (New York: Melville, 2011), 271-82. See further Karl Polanyi, The Livelihood of Man (New York: Academic Press, 1977).

33 For a fuller description of how this emotional logic functions within capitalism itself, see Martijn Konings, The Emotional Logic of Capitalism (Stanford, CA: Stanford University Press, 2015).

342 Corinthians $1.22,5.5$. For a discussion of how this concept functions later in the 
contrast, humanity makes or returns a sacrifice, then the cost of the sacrifice itself may function as evidence which guarantees the validity of a projected belief. Under such conditions, sacrifice substitutes means for ends: it becomes the reason why given ends are believed and trusted, for the price paid counts as evidence for their value. It may seem rather strange to propose a link between capitalism and religion in this way, such that personal religious commitments and sacrifices correspond, in the realm of belief, to capitalist investment. Likewise, capitalist investment, involving credit or downpayment on margin, may repeat the logic of religious faith. I am not the first to make such a link, and would like to offer the last words here, albeit rather suggestive ones, to another. Simone Weil compared Rosa Luxemburg's theory of capitalist war with Agamemnon's sacrifice of his daughter on the eve of the Trojan War: both sacrifice their nearest and dearest in a competitive struggle for the means of power, whether the blessings of the gods, or markets, money and the means of production. As a result, they can never abandon the quest for which such sacrifices have been made. Weil articulated the critical principle which may be used to evaluate capitalism and religion alike in terms of Homer's Iliad:

The real subject of the Iliad is the sway exercised by war over the warriors, and through them, over humanity in general; none of them knows why each sacrifices himself and all his family to a bloody and aimless war, and that is why, all through the poem, it is the gods who are credited with the mysterious influence which nullifies peace negotiations, continually revives hostilities, and brings together again the contending forces urged by a flash of good sense to abandon the struggle.

Thus in this ancient and wonderful poem there already appears the essential evil besetting humanity, the substitution of means for ends. At times war occupies the forefront, at other times the search for wealth, at other times production; but the evil remains the same. The common run of moralists complain that man is moved by his private interest: would to heaven it were so! Private interest is a selfcentred principle of action, but at the same time restricted, reasonable, and incapable of giving rise to unlimited evils. Whereas, on the other hand, the law of all activities governing social life, except in the case of primitive communities, is that each one sacrifices human life - in himself, and in others - to things which are only means to a better way of living. This sacrifice takes on various forms, but it all comes back to the question of power. Power, by definition, is only a means; or to put it better, to possess a power is simply to possess means of action which exceed the very limited force that a single individual has at his disposal. But powerseeking, owing to its essential incapacity to seize hold of its object, rules out all consideration of an end, and finally comes, through an inevitable reversal, to take the place of all ends. It is this reversal of the relationship between means and end, it is this fundamental folly that accounts for all that is senseless and bloody right

politics of Eusebius of Caesarea's praise of Constantine, see Devin Singh, Divine Currency (Stanford, CA: Standford University Press, 2018), 74-5. 
through history. Human history is simply the history of the servitude which makes men - oppressors and oppressed alike - the plaything of the instruments of domination they themselves have manufactured, and thus reduces living humanity to being the chattel of inanimate chattels. ${ }^{35}$

\section{References}

Amato, Massimo / Fantacci, Luca: The End of Finance, Cambridge, Polity, 2012.

Andréadès, Andreas: History of the Bank of England 1640-1903, London, Frank Cass, 1966.

Bank for International Settlements: Statistical Bulletin, December 2017.

Barnes, Kenneth: Redeeming Capitalism, Grand Rapids, MI, Eerdmanns, 2018.

Buchan, James: Frozen Desire: An Inquiry into the Meaning of Money, London, Picador, 1998.

Coggan, Philip: Paper Promises: Money, Debt and the New World Order, London, Allen Lane, 2011.

Das, Satyajit: A Banquet of Consequences: Have We Consumed our Own Future? London, Financial Times, 2016.

Douthwaite, Richard: Short Circuit: strengthening local economies for security in an unstable world, Dublin, Lilliput Press, 1996.

Dupuy, Jean-Pierre: Economy and the Future: A Crisis of Faith, trans. M.D. DeBevoise, East Lansing, MI, Michigan State University Press, 2014.

Galbraith, John Kenneth: Money: Whence it came, where it went, London, André Deutsch, 1975.

Geiselberger, Heinrich (ed.): The Great Regression, Cambridge, Polity, 2017.

Graeber, David: Debt: The First 5000 Years, New York, Melville, 2011.

Keen, Steve: Can We Avoid Another Financial Crisis? Cambridge, Polity, 2017.

King, Mervyn: The End of Alchemy: Money, Banking and the Future of the Global Economy, London, Little, Brown, 2016.

Konings, Martijn: The Emotional Logic of Capitalism, Stanford, CA, Stanford University Press, 2015.

Linklater, Andro: Owning the Earth: The Transforming History of Land Ownership, London, Bloomsbury, 2015.

Marx, Karl: Capital: Volume 1, Harmondsworth, Penguin, 1976.

Muldrew, Craig: The Economy of Obligation: The Culture of Credit and Social Relations in Early Modern England, Basingstoke, Palgrave, 1998.

Pettifor, Ann: The Production of Money, London, Verso, 2017.

Polanyi, Karl: The Livelihood of Man, New York, Academic Press, 1977.

Ross, Andrew: Creditocracy and the Case for Debt Refusal, New York, OR Books, 2013.

Roy, Olivier: Holy Ignorance: When Religion and Culture Part Ways, Oxford, Oxford University Press, 2014.

35 Simone Weil, Oppression and Liberty, trans. Arthur Wills (London: Routledge \& Kegan Paul, 1957) 68-9. 
Singh, Devin: Divine Currency, Stanford, CA, Standford University Press, 2018.

Turner, Adair: Between Debt and the Devil, Princeton, Princeton University Press, 2016.

Weber, Max: The Protestant Ethic and the Spirit of Capitalism, trans. Talcott Parsons, London, Allen and Unwin, 1965.

Weil, Simone: Oppression and Liberty, trans. Arthur Wills, London, Routledge \& Kegan Paul, 1957.

Wennerlind, Carl: Casualties of Credit: The English Financial Revolution 1620-1720, Cambridge, MA, Harvard University Press, 2015.

Wicksell, Knut: Interest and Prices, trans. R.F. Kahn, London, Macmillan, 1936.

\section{Internet Sources}

McLeay, Michael / Radia, Amar / Thomas, Ryland, "Money creation in the modern economy”, in: Bank of England Quarterly Bulletin Q1 2014, 14-28, available here: https://poseidon01.ssrn.com/delivery.php?ID=49609608511007502111809008512609 010109908308908000106310907200506512502109311608711109806203604011204610 909707809709902608809705409004004908707411701611510109110900900108000201 711301412608200106802709408108401801510908301601707000602400211209312010 $2 \& \mathrm{EXT}=$ pdf [September $\left.26^{\text {th }}, 2018\right]$.

Oxfam, An Economy for the 99 \% report January 2017: https://www.oxfam.org/en/re search/economy-99 [September $\left.25^{\text {th }}, 2018\right]$.

Philip Goodchild, Department of Philosophy, University of Nottingham, UK, e-mail: philip.goodchild@nottingham.ac.uk (ORCID ID: 0000-0002-8236-6721)

Citation: Goodchild, Philip: "Limits to Globalisation and the Loss of Faith", in: Appel, Kurt / Raschke, Carl (eds.): The Crisis of Representation (J-RaT 2018 / 2) pp. 84-100.

Datum der Publikation: 21.01.2018 